A Pilot Study of Natural Formulation Activity in the Protection of Stored Wheat and Barley Against the Stored-Product Insects

Pilot-istraživanje djelotvornosti prirodne formulacije u zaštiti uskladištene pšenice i ječma protiv skladišnih kukaca

Paponja, I., Rozman, V., Lucié, P., Liška, A.

Poljoprivreda/Agriculture

ISSN: $1848-8080$ (Online)

ISSN: 1330-7142 (Print)

https://doi.org/10.18047/poljo.27.2.5

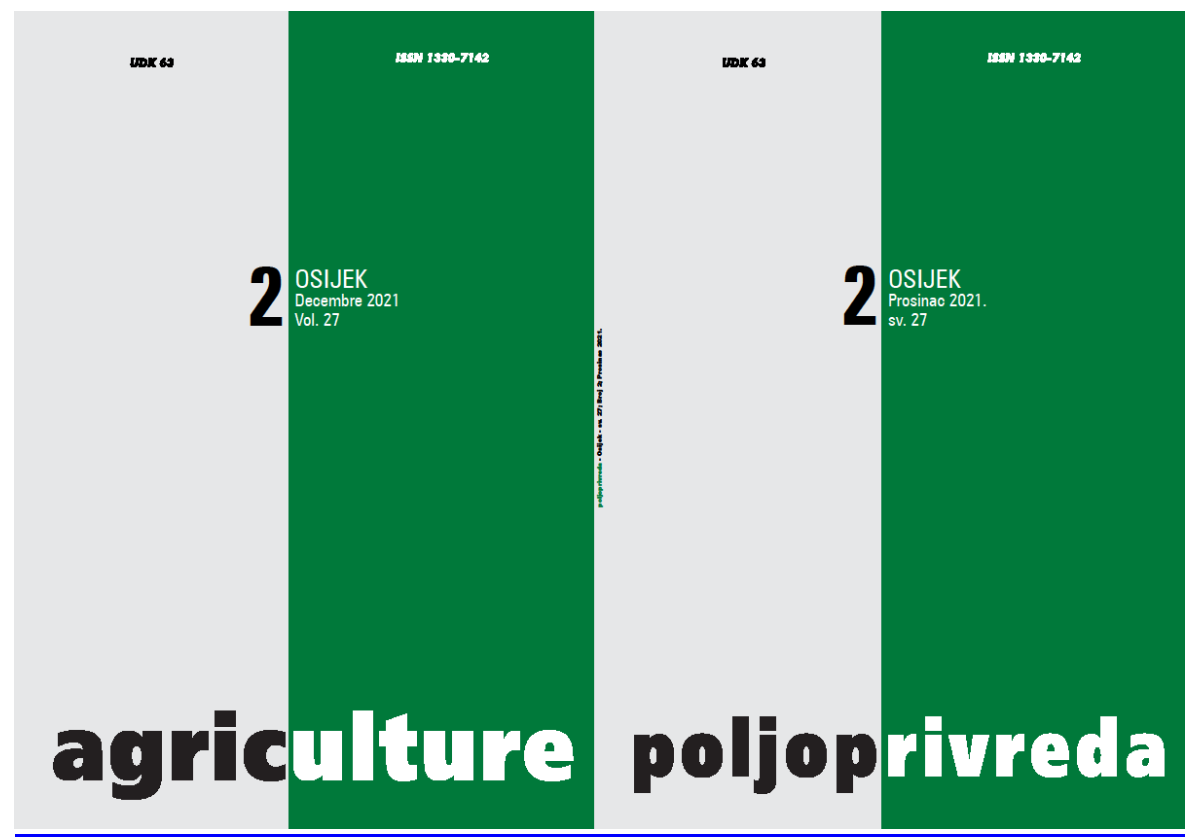

Fakultet agrobiotehničkih znanosti Osijek, Poljoprivredni institut Osijek

Faculty of Agrobiotechnical Sciences Osijek, Agricultural Institute Osijek 


\title{
A PILOT STUDY OF NATURAL FORMULATION ACTIVITY IN THE PROTECTION OF STORED WHEAT AND BARLEY AGAINST THE STORED-PRODUCT INSECTS
}

Paponja, I. ${ }^{(1)}$, Rozman, V. ${ }^{(2)}$, Lucić, P. ${ }^{(2)}$, Liška, A. ${ }^{(2)}$

\author{
Original scientific paper
}

Izvorni znanstveni članak

Summary

The stored-product insects are one of the major causes of losses in the stored cereals. Most of control measures still rely on a synthetic pesticide usage, but due to its negative side effects on the goods, human health, and the environment, there is an urgent need for an alternative control. A natural formulation based on the diatomaceous earth (DE) SilicoSec ${ }^{\circledR}$, enhanced with the botanicals (essential oil lavender, corn oil, and bay leaves dust) and the silica gel was developed. The aim of the study was to test the activity of the developed formulation as a postharvest protectant of seed wheat and barley in the suppression Sitophilus oryzae (L.), Rhyzopertha dominica (F.) and Tribolium castaneum (Herbst). As a reference comparative value, the DE SilicoSec ${ }^{\circledR}$ was applied. Subsequent to the six months of storage under the simulated warehouse conditions, the formulation has completely suppressed the initial population development of all three tested insect species, both in wheat and barley. In wheat, a complete suppression was detected at the dose of 500 ppm against T. castaneum and 600 ppm against both R. dominica and S. oryzae. In barley, a complete suppression was detected at the doses of 500 ppm, 400 ppm, and 600 ppm against R. dominica, T. castaneum and S. oryzae, respectively. Conclusively, the results of this study indicate that the developed natural formulation based on the DE, botanicals, and silica gel was highly effective against the three major stored-product insect species, providing a long-term safe storage of wheat and barley seeds.

Keywords: diatomaceous earth, botanicals, stored-product insects, long-term protectant, stored wheat, stored barley

\section{INTRODUCTION}

With regard to the current world population estimation, an increase amounting to 9 billion people is expected in the next 40 years (World Population Prospects, 2019). This will lead to a higher need for food production, especially for the cereals and other food grains. A major problem in storages is that of the harmful insects, which cause a substantial quality, quantity, economic and nutritional losses in agricultural products. Globally, approximately up to $40 \%$ of food grain loss has been reported due to insect pest infestation (Jayas, 2012; Mutambuki and Ngatia, 2012). A suppression of storedproduct insects is best achieved through an integration of chemical, physical, and biological methods (Phillips and Throne, 2010). However, in practice, there is still a strong reliance on the chemical insecticides (Hertlein et al., 2011). Recently, many international legislations have placed greater limitations on the use of toxic compounds, e.g., on the chemical insecticides, to preserve the food products (Adesina et al., 2019). This situation leads in the development of new natural insecticide formulations as a safe alternative to the toxic fumigants and other pesticides. One of the most common methods

(1) Ivan Paponja, Mag. Eng. Agr., (2) Prof. Dr. Vlatka Rozman, Ph. D., Pavo Lucić, Ph. D., Assoc. Prof. Anita Liška (aliska@fazos.hr) - University of Josip Juraj Strossmayer of Osijek, Faculty of Agrobiotechnical Sciences Osijek, Vladimira Preloga 1, 31000 Osijek, Croatia 
are the natural insecticides, such as the diatomaceous earth (DE). Due to its physical properties, the DE acts on the insects through a contact resulting in the desiccation and death (Ebeling, 1971; Ziaee et al., 2019). Because of its physical abilities, the DE provides a long-term protection of the stored products and also prevents reinfestation (Obeng-Ofori, 2010; Korunić et al., 2016). Thus, it could be regarded as a grain protectant with a low mammalian toxicity (Mortazavi et al., 2020). However, the $\mathrm{DE}$ has some limitations, such as a reduction in grain flowability, reduction of bulk density, ineffectiveness in inadequate conditions and a workers' discomfort due to an airborne dust (Korunić, 2013; Korunić et al., 2017). The other example of natural compounds used in the control of stored-product pests are the plant-derived compounds (Adesina et al., 2019; Paponja et al., 2020). Many researchers have reported on the botanicals with insecticidal properties (Belmain et al., 2001; Pavela, 2009; Rajashekar et al., 2013; Idoko and lleke, 2020; Isman, 2020; Lengai et al., 2020). Several botanicals act like the chemical insecticides, e.g., some essential oils (EOs) act like the natural fumigants, capable of killing an adult pest and reduce a progeny production (Rajashekar et al., 2013; Rozman et al., 2007). Botanicals such as these have a lot of advantages: they are harmless to humans and the environment, offer no residual effects, and are easy degradable and selective to the targeted pests (Khan et al., 2010). One key factor is that the DE activity takes time. The studies reported that an insect's death occurs when it loses $60 \%$ of water content. Overall, it identifies the DE as a slow-acting insecticide (Korunić et al., 2020). On the contrary, the botanicals, especially the Eos, have a fast toxic effect against the insects (Mossa, 2016). These two antagonisms are a good reason, in addition to the other benefits, for a combination of the DE with the botanicals, thus achieving a synergistic effect against the stored- product pests (Korunić et al., 2020). So far, there are numerous studies reported in which a synergistic effect was a key factor in the obtainment of better insecticidal results on pests (Yang et al., 2010; Korunić and Fields, 2018; Ziaee et al., 2019). In order to make the most out of the highlighted DE and botanicals advances and simultaneously minimize their disadvantages, we have tested a newly developed natural formulation as a postharvest grain (wheat and barley) protectant against the three major stored-product pest species, i.e., rice weevil Sitophilus oryzae (L.), lesser grain borer Rhyzopertha dominica (F.), and the red flour beetle Tribolium castaneum (Herbst), under the simulated warehouse conditions.

\section{MATERIALS AND METHODS}

\section{Natural formulation}

A powdered formulation labelled $N$ Form was based on the diatomaceous earth (DE) SilicoSec ${ }^{\circledR}(48 \%)$, silica gel Sipernat ${ }^{\circledR} 50 S(24 \%)$, dried and milled bay leaves $(20 \%)$, corn oil (3\%), lavender EO Lavandula x intermedia Emeric ex Loisel. (2\%) and an inactivated yeast as a food grade bait $(3 \%)$. All ingredients were mixed together in an electromagnetic sieve shaker (CISA RP08) using a $500 \mu \mathrm{m}$ mashed sieve. The prepared $N$ Form was kept in a hermetically sealed bottle until up to its application.

\section{Test insects}

The insecticidal effect of the $N$ Form formulation has been evaluated on the three stored-product insect species, two internal feeders, $S$. oryzae and $R$. dominica, and an external feeder, $T$. castaneum. The test insects have been reared under the controlled conditions at 28 $\pm 1{ }^{\circ} \mathrm{C}$ and $65 \pm 5 \% \mathrm{r}$. h. on the whole soft white wheat (for $S$. oryzae and $R$. dominica) and on a mixture of wheat flour and $5 \%$ brewer's yeast (for $T$. castaneum). All adults used in the test treatments were 7-21 d-old.

\section{Commodity}

For the experiment, the Croatian seed wheat and barley varieties were used, both produced by the Agricultural Institute Osijek. Bingo, a high-yield winter barley variety (protein content $11.02 \%$ ), had an initial m. c. amounting to $15.2 \%$ and $75.8 \mathrm{~kg} \mathrm{hL}^{-1}$ of the test weight, while a high-yield winter wheat variety Anđelka (protein content $13.0 \%$ and) was represented with $12.7 \%$ of an initial m. c. and $74.7 \mathrm{~kg} \mathrm{hL}^{-1}$ of the test weight. A moisture content and the wheat and barley test weights of were measured by the GAC 2100-Agri Grain analysis computer DICKEY-john). Prior to the use in a bioassay, the commodity was cleaned and sterilized under $50^{\circ} \mathrm{C}$ and acclimated for seven days at $28 \pm 1^{\circ} \mathrm{C}$ and $65 \pm 5 \%$ r. h.

\section{Bioassay in the simulated warehouse conditions}

To simulate the seed-storage warehouse conditions, the $7.5 \mathrm{~L}$ plastic containers were filled with $2 \mathrm{~kg}$ of wheat or barley, respectively, and four dosages $(300$, 400,500 and $600 \mathrm{ppm}$ ) of the prepared formulation were added. For equal distribution of the added dust, the entire container content was thoroughly mixed by a hand-held electric mixer. After the dust has settled, 50 unsexed adults of the $S$. oryzae, $R$. dominica and $T$. castaneum were jointly added into each container. The containers were closed with perforated plastic lids and left in a floor storage for six months. During the entire storage period, the storage-related microclimate conditions have been monitored. Thus, the air temperature and moisture during the six months of wheat storage ranged from $1^{\circ} \mathrm{C}$ to $24^{\circ} \mathrm{C}$ and from $75 \%$ r. h. to $95 \%$ r. h., respectively. The conditions during the barley storage ranged from $16^{\circ} \mathrm{C}$ to $24^{\circ} \mathrm{C}$ and from $76 \%$ r. h. to $89 \%$ r. h., respectively. All treatments were replicated three times for each dose or type of seed, respectively. The same procedure was followed for the untreated wheat and barley that served as a control. The DE SilicoSec ${ }^{\circledR}$ was also used and tested at the same doses and within the identical treatment as the $N$ Form. Subsequent to the completion of bioassay trial, the entire plastic container contents were sieved, and all insects, both the dead and the live ones, were counted. 


\section{Data analysis}

The bioassay results in the simulated warehouse conditions were presented graphically as a total number of developed adults per treatment or insect species, respectively, and the share of dead adults in respect to the number of initial populations. Due to a high density of developed insect population in the control treatment subsequent to a six-month period, the whole seed mass has turned into a sticky, compressed mass both in wheat and barley, so the control treatment was excluded from counting.

\section{RESULTS AND DISCUSSION}

Subsequent to the six months of storage in the simulated warehouse conditions, the $N$ Form formula- tion has provided an excellent protection of the treated wheat (Figure 1). It confirms completely suppression of the initial population of all three insect species, $R$. dominica and $S$. oryzae at the dosage of $600 \mathrm{ppm}$ (Figure 1a and Figure 1c, respectively) and $T$. castaneum at the dosage of $500 \mathrm{ppm}$ (Figure 1b). In comparison with the activity of the DE SilicoSec ${ }^{\circledR}$ at the lowest dosage (300 $\mathrm{ppm})$, a total number of adults found in the treatments with the $N$ Form was notably reduced: the $R$. dominica population of by 3.5 folds (Figure 1a), the $T$. castaneum population by 4.5 folds (Figure $1 \mathrm{~b}$ ), and the $S$. oryzae population by 1.9 folds (Figure 1c). Furthermore, the proportion of the dead insects found within the total number of adults was higher for all three insect species in almost all tested doses.
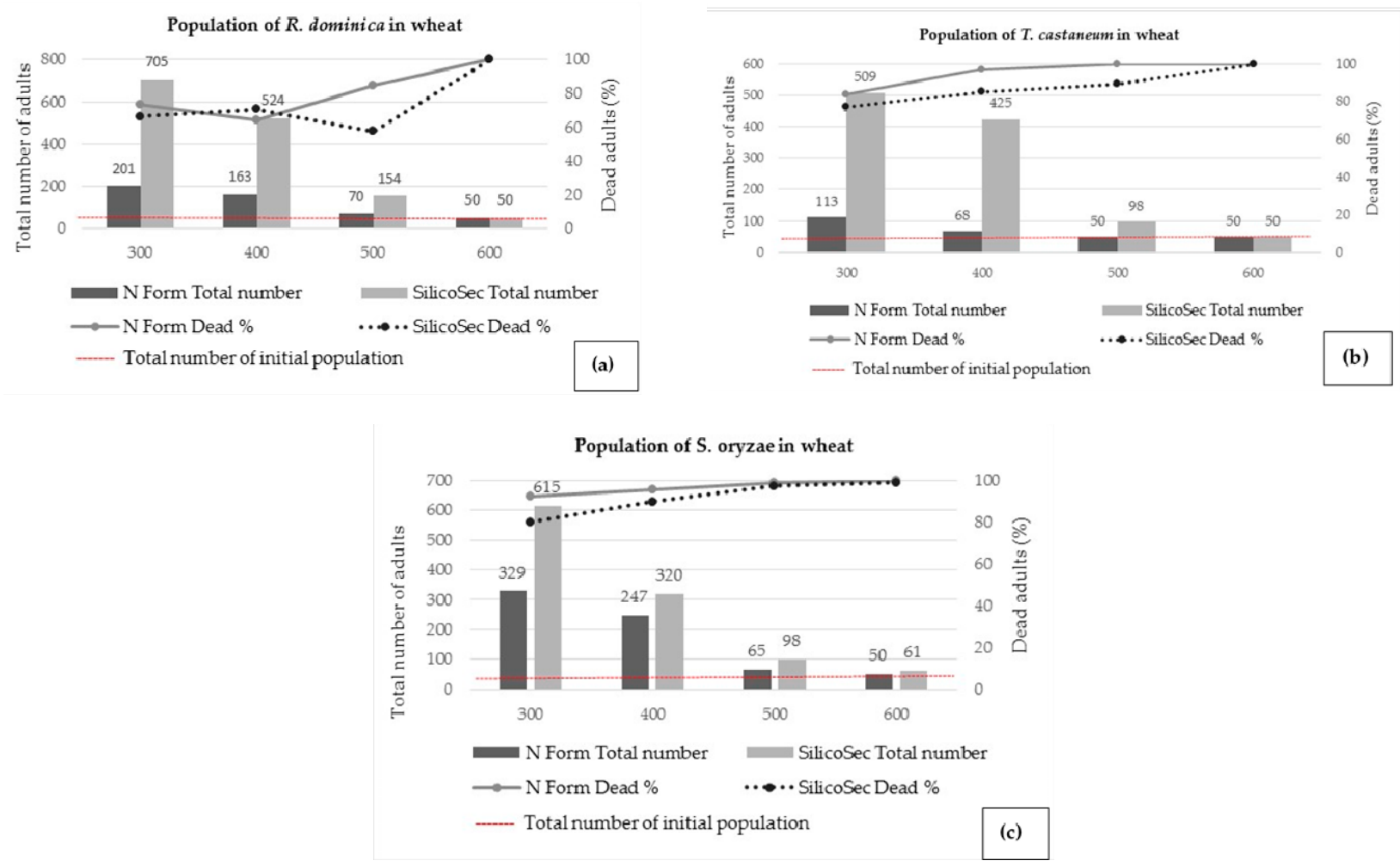

Figure 1. The adult insect population developed in the wheat seeds treated with the $N$ Form formulation and DE SilicoSec ${ }^{\circledR}$ subsequent to the six months of storage in the simulated warehouse conditions: (a) the adult $\boldsymbol{R}$. dominica population, (b) the adult $\boldsymbol{T}$. castaneum population, (c) the adult $S$. oryzae population

Grafikon 1. Populacija odraslih kukaca razvijenih u pšenici tretiranoj formulacijom N Form i DZ-om SilicoSec ${ }^{\circledR}$ nakon šest mjeseci skladištenja u simuliranim skladišnim uvjetima: (a) populacija odraslih R. dominica, (b) populacija odraslih T. castaneum, (c) populacija odraslih S. oryzae

In barley, the $N$ Form formulation has provided an excellent protection against $R$. dominica and $S$. oryzae subsequent to a six-month period (Figure 2). A complete suppression of the initial population of $R$. dominica, $T$. castaneum, and $S$. oryzae was detected at the dosages of $500 \mathrm{ppm}, 400 \mathrm{ppm}$, and $600 \mathrm{ppm}$, respectively (Figure $2 a, 2 b$, and $2 c$, respectively). Nonetheless, an increase in the total number of $T$. castaneum adults was observed at the higher dosages (500 ppm and $600 \mathrm{ppm}$ ) of both the $N$ Form and of the DE SilicoSec ${ }^{\circledR}$. In comparison with the activity of the DE SilicoSec ${ }^{\circledR}$ at the lowest dosage $(300 \mathrm{ppm})$, a total number of adults found in the treatment with $N$ Form was notably reduced: the $R$. dominica population by 1.2 folds (Figure $2 \mathrm{a}$ ) and the $S$. oryzae population by 1.3 folds (Figure $2 \mathrm{c}$ ). Additionally, the proportion of dead insects found within the total number of adults was higher in all three insect species concerning all tested doses. 

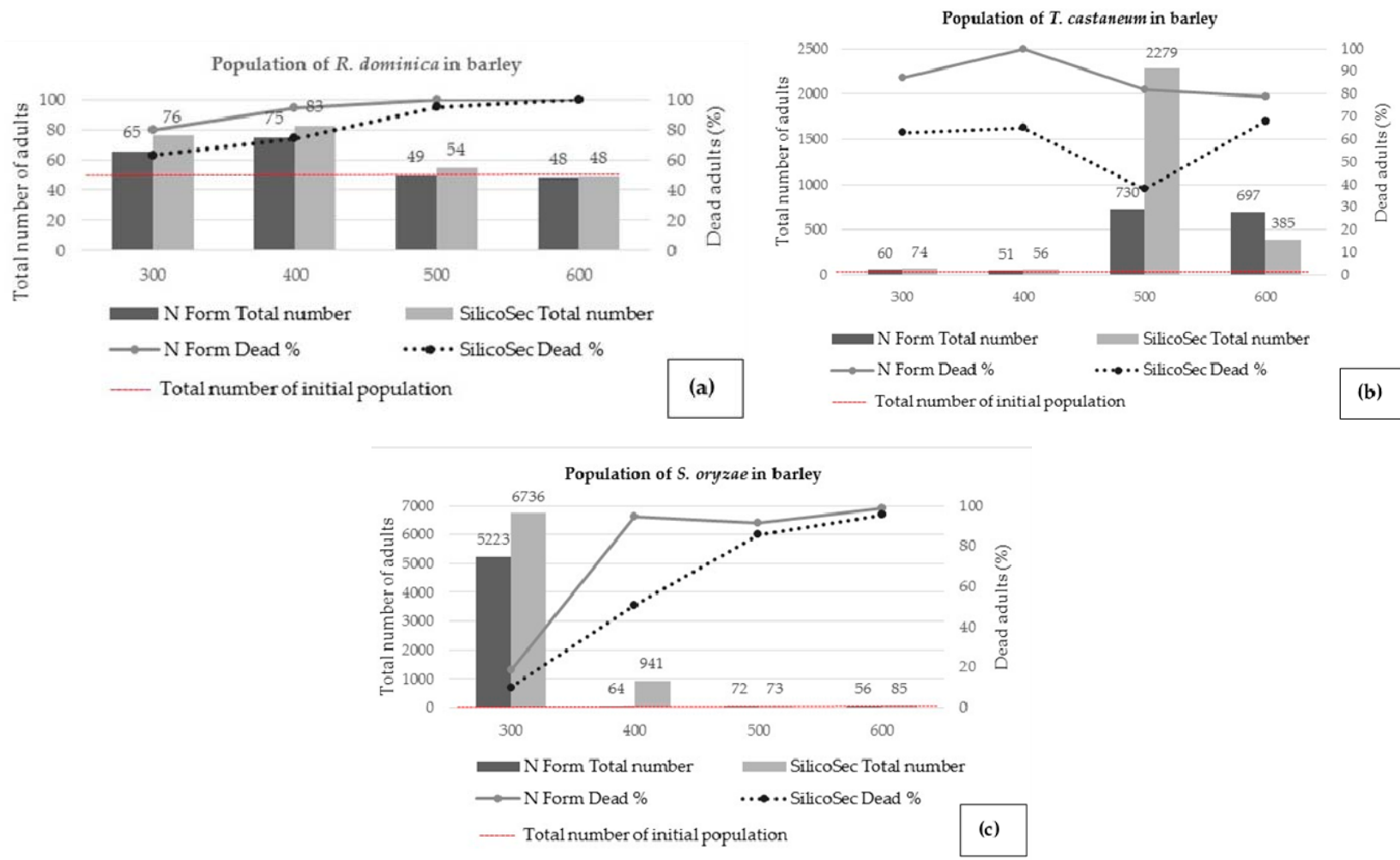

Figure 2. The adult insect population developed in the barley seeds treated with the $\boldsymbol{N}$ Form formulation and the DE SilicoSec ${ }^{\circledR}$ subsequent to the six months of storage in the simulated warehouse conditions: (a) the adult $R$. dominica population, (b) the adult $T$. castaneum population, (c) the adult $S$. oryzae population

Grafikon 2. Populacija odraslih kukaca razvijenih u ječmu tretiranom formulacijom N Form i DZ-om SilicoSec ${ }^{\circledR}$ nakon šest mjeseci skladištenja u simuliranim skladišnim uvjetima: (a) populacija odraslih R. dominica, (b) populacija odraslih T. castaneum, (c) populacija odraslih S. oryzae

Subsequent to the six months of wheat storage, the $N$ Form has completely suppressed the initial populations of $S$. oryzae, $R$. dominica, and $T$. castaneum and has simultaneously manifested a notably better performance when compared to the DE SilicoSec ${ }^{\circledR}$. A better performance of the $N$ Form was achived due to its ingredients with a proven insecticidal activity and a different action mode that has eventually contributed to its overall activity. In addition to a well-known activity of botanicals and the $D E$, the usage of vegetable oils (such as the coconut oil, palm oil, sunflower oil, sesame oil or corn oil) mixed with the grains is demonstrated as a storage protectant (Obeng-Ofori, 2010). Nevertheless, this storage-protective behavior of vegetable oils has not been integrally comprehended so far, as such an activity of theirs could have been provoked by both the physical and chemical factors (Don Pedro, 1989). What is more, the silica gels, made up of silicon dioxide for up to $99.5 \%$ and having the extremely small particles, sized less than $3 \mu \mathrm{m}$ (Quarles, 1992), have an excellent absorbing capacity, which makes them more effective than the DE (Subramanyam and Roesli, 2000).

There are not many studies of the DE and DE formulations conducted in the course of the field trials. Many factors may, namely, reduce their efficacy, especially the microclimate changes during the storage (Stathers et al., 2004; Pierattini et al., 2019). An increase in the m. c. or $r$. h. of the treated grain will consideralbly reduce the DE efficacy, especially if the m. c. is more than $14 \%$, or if the r. h. exceeds $70 \%$ (Korunic, 1998; Losic and Korunic, 2018).

According to the results obtained subsequent to a six-month period, an unexpected increase in the T. castaneum population in barley has occurred concomitant with the application of higher dosages of both the $N$ Form and the DE SilicoSec ${ }^{\circledR}$. Since the populations of $S$. oryzae and $R$. dominica have continued to decrease under the same conditions and treatment, we assumed that an increase in the populations might be an adaptive strategy of $T$. castaneum to stress situations. Roth and Kurtz (2008) revealed that the $T$. castaneum is able to speed up its development when the immune defense is stimulated. It was previously observed that the larval weight and survival in $T$. castaneum were significantly higher than those of a control group after the larvae had been fed by the hermetic concentrations of azadirachtin (Mukherjee et al., 1993). Furthermore, the previously mentioned authors suggest that the hermetic concentration of azadirachtin affect the synthesis or repression of esterase in the $T$. castaneum larvae, which assists 
them to grow and survive more efficiently, since the esterase has been implicated in the hormone metabolism and digestion (Kapin and Ahmad, 1980). According to Cutler (2013), it has been noted for quite a long time that, following an insecticides application, there is an occasional surge in insect population growth at a rate greater than the one that would have been observed without the aforementioned application, pointing out the importance of this hormesis phenomenon. Although hormesis is a consequence of the application of sublethal insecticide dosages, an increase in the number of populations in our study has appeared in the treatment with higher dosages of $N$ Form and the DE (500 and $600 \mathrm{ppm})$. Comparing the number of adults developed at the $400 \mathrm{ppm}$ dosage to the one developed after two dosages, whereby a population increase was observed, the $T$. castaneum population has increased by 14.4 folds and 13.7 folds, respectively, concerning the $N$ Form and by 40.5 folds and 6.8 folds, respectively, concerning the DE. It is not possibly directly related to the hormesis phenomenon, but, apparently, the adult insects in barley treated with the higher dosages have responded to the changes in behavior and reproduction.

\section{CONCLUSION}

This study's results validate that the developed natural $N$ Form formulation, based on the DE, botanicals, and silica gel, was highly effective against the three major store-product insect species tested, i.e., the $S$. oryzae, $R$. dominica, and $T$. castaneum, providing for a long-term protection of both the wheat and barley seeds. Subsequent to a six-month storage period in the simulated warehouse conditions, the results indicate the achievement of a higher efficacy of the natural $N$ Form formulation than that of the DE SilicoSec ${ }^{\circledR}$ alone. These results prove a synergistic activity and provide a new information about the enhancement of DE efficacy, which can be considered as a further step in the development of natural insecticides as a part of an integrated pest management (IPM). A further research is required, related to the influence of such natural formulations on a bulk density, bulk flowability, and grain quality. Some other tests can be conduct in relation to the other insect species and their progeny, and some other treatments may be applied concerning the empty storage facilities.

\section{ACKNOWLEDGEMENTS}

The study was carried out within the Research Team on Environmentally Acceptable Plant Protection (No. 1133) at the Faculty of Agrobiotechnical Sciences Osijek.

\section{REFERENCES}

1. Adesina, J.M., Raghavendra, A., Rajashekar, Y., Ofuya T.I. (2019). Potential use of Clerodendrum capitatum extracts and its formulation for control of three major stored product beetles. Food Quality and Safety, 3, 179185. https://doi.org/10.1093/fqsafe/fyz018

2. Belmain, S. R., Neal, G. E., Ray, D. E., Golob, P. (2001). Insecticidal and vertebrate toxicity associated with ethnobotanicals used as post-harvest protectants in Ghana. Food and Chemical Toxicology, 39(3), 287-291. https://doi.org/10.1016/S0278-6915(00)00134-4

3. Cutler, G.C. (2013). Insects, Insecticides and Hormesis: Evidence and Considerations for Study. Dose-Response, 11(2), 154-177.

https://doi.org/10.2203/dose-response.12-008.Cutler

4. Don-Pedro, K.N. (1989). Mechanisms of action of some vegetable oils against Sitophilus zeamais Motschulsky (Coleoptera: Curculionidae) on wheat. Journal of Stored Product Research, 25, 217-223.

5. Ebeling, W. (1971). Sorptive Dusts for Pest Control. Annual Review of Entomology, 16(1), 123-158. https://doi.org/10.1146/annurev.en.16.010171.001011

6. Hertlein, M.B., Thompson, G.D., Subramanyam, B., Athanassiou C.G. (2011). Spinosad: A new natural product for stored grain protection. Journal of Stored Products Research, 47(3), 131-146. https://doi.org/10.1016/j.jspr.2011.01.004

7. Idoko, J.E., lleke, K.D. (2020). Comparative evaluation of insecticidal properties of essential oils of some selected botanicals as bio-pesticides against Cowpea bruchid, Callosobruchus maculatus (Fabricius) (Coleoptera: Chrysomelidae). Bulletin of the National Research Centre, 44(1), 119. https://doi.org/10.1186/s42269-020-00380-2

8. Isman, M.B. (2020). Botanical Insecticides in the TwentyFirst Century - Fulfilling Their Promise? Annual Review of Entomology, 65(1), 233-249.

https://doi.org/10.1146/annurev-ento-011019-025010

9. Jayas, D.S. (2012). Storing Grains for Food Security and Sustainability. Agricultural Research, 1(1), 21-24. https://doi.org/10.1007/s40003-011-0004-4

10. Kapin, M.A., Ahmad, S. (1980). Esterases in larval tissues of gypsy moth, Lymantria dispar (L.): optimum assay conditions, quantification and characterization. Insect Biochemistry, 10(3), 331-337. https://doi.org/10.1016/0020-1790(80)90028-1

11. Khan, I., Afsheen, S., Din, N., Khattak, S., Khalil, S. K., Lou, Y. H. Y. (2010). Appraisal of Different Wheat Genotypes Against Angoumois Grain Moth, Sitotroga ceralella (Oliv). Pakistan Journal of Zoology, 42(2), 161 168.

12. Korunic, Z. (1998). Review Diatomaceous earths, a group of natural insecticieds. Journal of Stored Products Research, 34(2-3), 87-97. https://doi.org/10.1016/S0022-474X(97)00039-8

13. Korunić, Z. (2013). Diatomaceous Earths - Natural Insecticides. Pesticides and Phytomedicine, 28(2), 77-95. https://doi.org/10.2298/PIF1302077K

14. Korunić, Z., Rozman, V., Liška, A., Lucić, P. (2016). A review of natural insecticides based on diatomaceous eathrs. Poljoprivreda/Agriculture, 22(1), 10-18. https://dx.doi.org/10.18047/poljo.22.1.2 
15. Korunic, Z., Rozman, V., Liska, A., Lucic, P. (2017). Laboratory tests on insecticidal effectiveness of disodium octaborate tetrahydrate, diatomaceous earth and amorphous silica gel against Sitophilus oryzae (L.) and their effect on wheat bulk density. Poljoprivreda/ Agriculture, 23(1), 3-10.

https://doi.org/10.18047/poljo.23.1.1

16. Korunic, Z., Fields, P.G. (2018). Evaluation of the new insecticide formulations based on inert dusts and botanicals against four stored e grain beetles. In: Adler, C.S., et al. (Eds.), Proceedings of The $12^{\text {th }}$ International Working Conference on Stored Product Protection IWCSPP, Julius Kühn-Institut, Berlin, Germany, 807-808.

17. Korunić, Z., Liška, A., Lucić, P., Hamel, D., Rozman, V. (2020). Evaluation of diatomaceous earth formulations enhanced with natural products against stored product insects. Journal of Stored Products Research, 86, 101565. https://doi.org/10.1016/j.jspr.2019.101565

18. Lengai, G.M.W., Muthomi, J.W., Mbega, E.R. (2020). Phytochemical activity and role of botanical pesticides in pest management for sustainable agricultural crop production. Scientific African, 7, e00239. https://doi.org/10.1016/j.sciaf.2019.e00239

19. Losic, D.; Korunic, Z. (2018). Diatomecaous earth, A natural insecticides for stored grain protection: recent progress and perspective. Nanoscience \& Nanotechnology Series No. 44. Diatom Nanotec hnology: Progress and Emerging Applications. Losic, D. (Ed.), The Royal Society of Chemistry, 2018.

20. Mortazavi, H., Toprak, U., Emekci, M., Bagci, F., Guray Ferizli, A. (2020). Persistence of diatomaceous earth, SilicoSec $₫$ against three stored grain beetles. Journal of Stored Products Research, 89, 101724. https://doi.org/10.1016/j.jspr.2020.101724

21. Mukherjee, S.N., Rawal, S.K., Ghumare, S.S., Sharma, R.N. (1993). Hormetic concentrations of azadirachtin and isoesterase profiles in Tribolium castaneum (Herbst) (Coleoptera: Tenebrionidae). Experientia, 49, 557-560. https://doi.org/10.1007/BF01955163

22. Mossa, A.T.H. (2016). Green Pesticides: Essential Oils as Biopesticides in Insect-pest Management. Journal of Environmental Science and Technology, 9(5), 354-378. https://doi.org/10.3923/jest.2016.354.378

23. Mutambuki, K., Ngatia, C. M. (2012). Assessment of grain damage and weight loss on farm stored maize in highlands areas of Bungoma district, Kenya. Journal of Agricultural Science and Technology, 2(3), 349-361.

24. Obeng-Ofori, D. (2010). Residual insecticides, inert dust and botanicals for the protection of durable stored products against pest infestation in developing countries. In: Carvalho, M.O., et al. (Eds.), Proceedings of The $10^{\text {th }}$ International Working Conference on Stored Product Protection IWCSPP, Julius Kühn-Archiv 425, Estoril, Portugal, 774-788.

25. Paponja, I., Rozman, V., Liška, A. (2020). Natural Formulation Based on Diatomaceous Earth and
Botanicals against Stored Product Insects. Insects, 11(9), 613. https://doi.org/10.3390/insects 11090613

26. Pavela, R. (2009). Effectiveness of Some Botanical Insecticides against Spodoptera littoralis Boisduvala (Lepidoptera: Noctudiae), Myzus persicae Sulzer (Hemiptera: Aphididae) and Tetranychus urticae Koch (Acari: Tetranychidae). Plant Protection Science, 45(4), 161-167. https://doi.org/10.17221/16/2009-PPS

27. Phillips, T.W., Throne, J.E. (2010). Biorational Approaches to Managing Stored-Product Insects. Annual Review of Entomology, 55, 375-397.

https://doi.org/10.1146/annurev.ento.54.110807.090451

28. Pierattini, E.C., Bedini, S., Venturi, F., Ascrizzi, R., Flamini, G., Bocchino, R., Girardi, J., Giannotti, P., Ferroni, G., Conti, B. (2019). Sensory Quality of Essential Oils and Their Synergistic Effect with Diatomaceous Earth, for the Control of Stored Grain Insects. Insects, 10, 114. https://doi.org/10.3390/insects10040114

29. Quarles, W. (1992). Silica gel for pest control. IPM Practitioner 14, 1-11.

30. Rajashekar, Y., Kumar, H. V., Ravindra, K. V., Bakthavatsalam, N. (2013). Isolation and characterization of biofumigant from leaves of Lantana camara for the control of stored grain insect pests. Industrial Crops Products, 51, 224-228.

https://doi.org/10.1016/j.indcrop.2013.09.006

31. Roth, 0., Kurtz, J. (2008). The stimulation of defence accelerates development in the red flour beetle (Tribolium castaneum). Journal of Evolutionary Biology, 21, 17031710.

https://doi.org/10.1111/j.1420-9101.2008.01584.x

32. Rozman, V., Kalinovic, I., Korunic, Z. (2007). Toxicity of naturally occurring compounds of Lamiaceae and Lauraceae to three stored-product insects. Journal of Stored Products Research, 43(4), 349-355.

https://doi.org/10.1016/j.jspr.2006.09.001

33. Stathers, T.E., Denniff, M., Golob, P. (2004). The efficacy and persistence of diatomaceous earths admixed with commodity against four tropical stored product beetle pests Journal of Stored Products Research, 40(1), 113123. https://doi.org/10.1016/S0022-474X(02)00083-8

34. Subramanyam, Bh., Roesli, R. (2000). Inert dusts. In: Subramanyam, Bh., Hagstrum, D.W. (Eds), Alternatives to Pesticides in Stored-Product IPM. Kluwer Academic Publishers, Boston, USA, pp. 321-380.

35. World Population Prospects: The 2019 Revision, www. Worldmeters.info

36. Yang, F.L., Liang, G.W., Xu, Y.J., Lu, Y.Y., Zeng, L. (2010). Diatomaceous earth enhances the toxicity of garlic, Allium sativum, essential oil against stored-product pests. Journal of Stored Products Research, 46(2), 118123. https://doi.org/10.1016/j.jspr.2010.01.001

37. Ziaee, M., Ebadillahi, A., Wakil, W. (2019): Integrating inert dusts with other technologies in stored product protection. Toxin Reviews.

https://doi.org/10.1080/15569543.2019.1633673 


\section{PILOT-ISTRAŽIVANJE DJELOTVORNOSTI PRIRODNE FORMULACIJE U ZAŠTITI USKLADIŠTENE PŠENICE I JEČMA PROTIV SKLADIŠNIH KUKACA}

\section{SAŽETAK}

Skladišni kukci jedan su od glavnih uzroka nastanka gubitka uskladištenih žitarica. Većina mjera zaštite $i$ dalje se oslanja na primjenu sintetičkih pesticida, ali zbog njihova negativnoga utjecaja na robu, ljudsko zdravlje $i$ okoliš, velika je potreba za alternativnim mjerama zaštite. Razvijena je prirodna formulacija na bazi dijatomejske zemlje (DZ) SilicoSec ${ }^{\circledR}$, obogaćena botaničkim komponentama (eteričnim uljem lavandina, kukuruznim uljem i prahom lovorova lišća) te silikagelom. Cilj istraživanja bio je testirati djelotvornost razvijene formulacije kao zaštitnoga sredstva uskladištenoga zrna pšenice i ječma u suzbijanju Sitophilus oryzae (L.), Rhyzopertha dominica (F.) $i$ Tribolium castaneum (Herbst). Kao referentna usporedna vrijednost korištena je DZ SilicoSec ${ }^{\circledR}$. Nakon šest mjeseci čuvanja u simuliranim skladišnim uvjetima, formulacija je u potpunosti suzbila razvoj početne populacije svih triju testiranih vrsta kukaca u pšenici $i$ u ječmu. U pšenici je potpuna inhibicija postignuta pri dozi od 500 ppm kod T. castaneum te pri dozi od 600 ppm kod R. dominica $i$ S. oryzae. U ječmu je potpuna inhibicija postignuta pri dozama od 500 ppm, 400 ppm i 600 ppm kod R. dominica T. castaneum i S. oryzae. Zaključno, rezultati ovoga istraživanja ukazuju na vrlo visoku učinkovitost razvijene prirodne formulacije na bazi dijatomejske zemlje, botaničkih komponenata i silikagela protiv triju glavnih vrtsa skladišnih kukaca, osiguravajući dugotrajnu zaštitu uskladištenoga zrna pšenice i ječma.

Ključne riječi: dijatomejska zemlja, botaničke komponente, skladišni kukci, dugotrajno zaštitno sredstvo, uskladištena pšenica, uskladišteni ječam

(Received on July 23, 2021; accepted on November 3, 2021 - Primljeno 23. srpnja 2021.; prihvaćeno 3. studenoga 2021.) 